ANL/CMB/PP - 90377

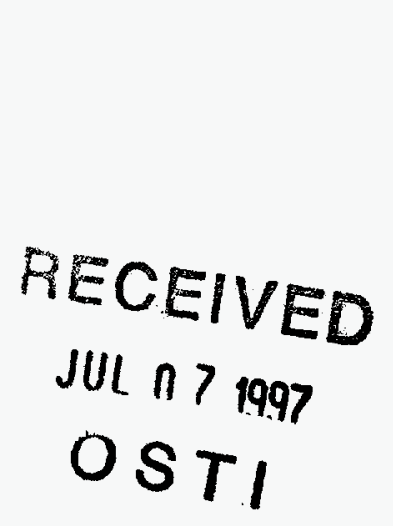

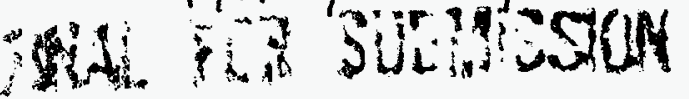

$11 / 18 / 96$

90377

November 15, 1996

\title{
Human Macrophage Differentiation Involves an Interaction between Integrins and Fibronectin ${ }^{1}$
}

\author{
Amale Laouar, Cynthia B.H. Chubb, Frank Collart, and \\ Eliezer Huberman ${ }^{2}$
}
Center for Mechanistic Biology and Biotechnology
Argonne National Laboratory
9700 South Cass Avenue
Argonne, Illinois 60439-4833

\begin{abstract}
The submitted manuscript has been created by the University of Chicago as Operator of Argonne National Laboratory ("Argonne") under Contract No. W-31-109-ENG-38 with the U.S. Department of Energy. The U.S. Government retains for itself, and others acting on its behalf, a paid-up, nonexclusive, irrevocable worldwide license in said anticle to reproduce, prepare derivative works, distribute copies to the public, and perform publicly and display publicly, by or on behall of

the Government.
\end{abstract}

${ }^{1}$ Work supported by the U.S. Department of Energy, Office of Health and Environmental Research, under Contract W-31-109-ENG-38.

${ }^{2}$ To whom communications and requests for reprints should be addressed, at 9700 South Cass Avenue, Argonne, Illinois 60439-4833.

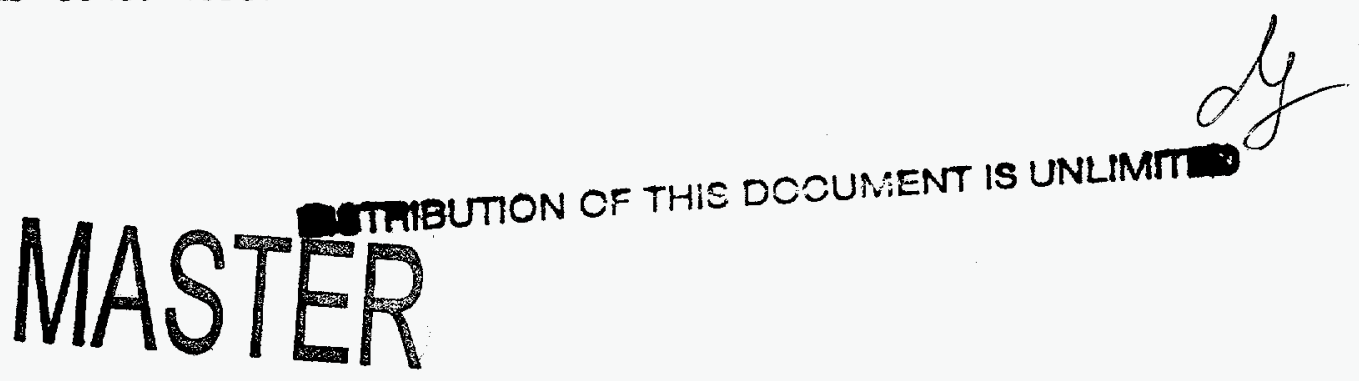




\section{Abbreviations}

RA

all-trans-retinoic acid

BSA

bovine serum albumin

ECM

extracellular matrix

FN

fibronectin

M-CSF

macrophage-colony stimulating factor

MAb

monoclonal antibody

PBS

phosphate-buffered saline

PKC

protein kinase $\mathrm{C}$

PMA

phorbol 12-myristate 13-acetate

VLA

very late after activation antigens $\left(\beta_{1}\right.$ integrin family of receptors)

\section{DISCLAIMER}

This report was prepared as an account of work sponsored by an agency of the United States Government. Neither the United States Government nor any agency thereof, nor any of their employees, makes any warranty, express or implied, or assumes any legal liability or responsibility for the accuracy, completeness, or usefulness of any information, apparatus, product, or process disclosed, or represents that its use would not infringe privately owned rights. Reference herein to any specific commercial product, process, or service by trade name, trademark, manufacturer, or otherwise does not necessarily constitute or imply its endorsement, recommendation, or favoring by the United States Government or any agency thereof. The views and opinions of authors expressed herein do not necessarily state or reflect those of the United States Government or any agency thereof. 


\section{DISCLAMMER}

Portions of this document may be illegible in electronic image products. Images are produced from the best available original document. 


\begin{abstract}
We have examined the role of the $\beta_{1}$ integrin family of adhesion receptors (VLA) and the extracellular matrix protein fibronectin (FN) in macrophage differentiation of 1) human HL-60 myeloid leukemia cells induced by phorbol 12-myristate 13-acetate (PMA) and 2) human peripheral blood monocytes induced by either PMA or macrophage-colony stimulating factor (MCSF). Increased VLA and FN gene expression was observed as early as $4 \mathrm{~h}$ after PMA treatment of $\mathrm{HL}-60$ cells and PMA- or M-CSF-treatment of monocytes, and it preceded the manifestation of macrophage markers. Treated HL-60 cells and monocytes also released and deposited FN on the surface of the tissue culture dishes. An HL-60 cell variant, HL-525, which is deficient in protein kinase $C \beta$ and resistant to PMA-induced differentiation, exhibited elevated levels of the VLA antigen but failed to express the FN gene. Incubation of HL-525 cells on dishes precoated with exogenous FN resulted in a macrophage differentiation. The macrophage phenotype induced in $\mathrm{HL}-60$ cells, HL-525 cells, or monocytes was attenuated to various degrees by anti-VLA or anti-FN MAbs or by exogenous RGDS, a VLA-binding motif on FN. We suggest that macrophage differentiation is initiated by the activation of protein kinase $\mathrm{C}$, which leads to the expression of the integrin, FN and related genes. The integrins mediate cell attachment and spreading on appropriate substrates by binding to deposited extracellular proteins such as FN. This attachment and spreading, in turn, leads to the expression of genes that code for the macrophage functions.
\end{abstract}




\section{INTRODUCTION}

The extracellular matrix (ECM) is an intricate assembly of proteins that includes collagen, laminin, and fibronectin, among others (1). Cells interact with these proteins and with each other via specific receptors located on their surface. A major class of these receptors is the integrins, each of which is composed of two distinct $\alpha$ and $\beta$ transmembrane glycoprotein subunits that are noncovalently linked (2). The integrins are classified into families of receptors. For example, the $\beta_{1}$ integrin family, also called very late after activation antigens (VLA), is implicated in cell adhesion to the ECM (2); a member of this family, VLA4, is also involved in cell-cell interactions (3). The integrins bind to specific recognition sites on ECM proteins. One of these sites, which is present on fibronectin (FN), is composed of an Arg-Gly-Asp-Ser (RGDS) motif (4). Synthetic peptides containing RGDS have been found to promote cell adhesion when immobilized on suitable substrates and to inhibit cell adhesion to tissue culture dishes precoated with FN (5).

Macrophages adhere to, spread on, and engulf foreign particles, including microorganisms; adherence and spreading on foreign substrates (including tissue culture dishes) are considered to be hallmarks of macrophages. A number of ECM proteins have been shown to enhance the maturation of blood monocytes into macrophages (6-8). It is thus conceivable that adhesion molecules not only define macrophage characteristics but also participate in the process that leads to macrophage differentiation. We report here the role specific adhesion molecules, FN in particular, play in macrophage differentiation of human leukemia cells and monocytes. 


\section{MATERIALS AND METHODS}

Reagents. Isotypic controls $\left(\operatorname{IgG}_{1}, \operatorname{IgG}_{2 \mathrm{a}}\right.$ and $\left.\mathrm{IgG}_{2 \mathrm{~b}}\right)$, murine monoclonal antibodies (MAbs) to human fibronectin (FN-15, $\operatorname{lgG}_{1}$ ), an $\alpha$-naphthyl acetate esterase assay kit, RGDS and GPRP peptides, all-trans-retinoic acid (RA), and Ficoll-Hypaque were purchased from Sigma Chemical Co. (St. Louis, MO). Anti-VLA MAb, an antibody to the human $\beta_{1}$ chain of VLA, $\mathrm{CD}_{29}$ (K20, $\left.\mathrm{IgG}_{2 \mathrm{a}}\right)$; and human $\alpha_{5}$ chain integrin, $\mathrm{CD}_{49} \mathrm{e}\left(\mathrm{SAM} 1, \mathrm{IgG}_{2 \mathrm{~b}}\right)$ were purchased from Immunotech (Westbrook, ME). Indocarcyanine-conjugated anti-murine goat immunoglobulin $\left(\mathrm{CY}^{\mathrm{TM}}\right)$ was purchased from Jackson Immunoresearch Lab, Inc., (West Grove, PA), and anti-human integrin $\alpha_{v} \beta_{3}$ complex, $\mathrm{CD}_{51} / \mathrm{CD}_{61} \mathrm{MAb}\left(23 \mathrm{C}_{\mathrm{G}}, \mathrm{IgG}_{1}\right.$ ) from Pharmingen (San Diego, $\mathrm{CA}$ ). Anti-human $\beta_{4}$ integrin was kindly provided by Dr. S. Kennel (Oak Ridge National Laboratory). M-CSF was purchased from Biosource International (Camarilo, $\mathrm{CA}$ ), and plates precoated with either mouse laminin, collagen type I, or collagen type IV from Becton Dickinson (Bedford, MA).

Cells and Cell Culture. The human myeloid HL-60 leukemia cell line was originally obtained from R.C. Gallo (National Cancer Institute). The HL-525 and HL-534 cells $(9,10)$, as well as the HL-525 cells transfected with either PKC $\dot{\beta}_{1}$ cDNA (HL-525/ßI-C and HL-525/ßI-F) or control vector (HL-525/neo), were established in our laboratory (11). Monocytes were obtained from heparinized whole human venous blood and separated by Ficoll-Hypaque density gradient (1.077 $\mathrm{g} / \mathrm{ml}$ ) centrifugation as previously described (12). The cells were incubated in tissue culture plates with RPMI 1640 medium supplemented with $15 \%$ heat-inactivated fetal calf serum (Intergen Co., NY), $100 \mu \mathrm{g} / \mathrm{ml}$ penicillin-streptomycin, and $2 \mathrm{mM}$ L-glutamine (Life 
Technologies, Inc., Grand Island, NY) in a humidified atmosphere containing $8 \% \mathrm{CO}_{2}$ at $37^{\circ} \mathrm{C}$.

Differentiation markers. To determine the percentage of adherent and spread cells, we inoculated $(2.5-5) \times 10^{5}$ cells in $0.5 \mathrm{ml}$ of medium into each well of a 24-well tissue culture plate in the presence or absence of PMA or M-CSF. For some experiments, we precoated the surface of the wells with either FN or bovine serum albumin (BSA) by overnight incubation at room temperature with $0.5 \mathrm{ml}$ solution containing $20 \mu \mathrm{g}$ protein $/ \mathrm{ml}$. The nonspecific sites were blocked with $1 \% \mathrm{BSA}$ in PBS for $30 \mathrm{~min}$. The wells were then washed with $3 \mathrm{mM} \mathrm{MnCl}$, inoculated with the cells, and incubated for different time intervals. The percentage of cell attachment and cell spreading was determined as previously described (13). The fraction of attached cells was up to $20 \%$ higher than the percentage of attached cells with apparent spreading. Nonspecific esterase activity was determined by using the $\alpha$-naphthyl acetate esterase assay kit as described by the manufacturer. Phagocytosis was determined as described previously (11) by the ability of cells to ingest sterilized and opsonized 1.7- $\mu \mathrm{m}$ (diameter) Fluoresbrite beads (Polysciences Inc., Warrington, PA). Cells were considered positive if they engulfed $\geq 20$ beads per cell. To examine the blocking effect of MAbs or peptides on differentiation induction, we incubated the cells with the dialyzed MAb or the peptide for $20 \mathrm{~min}$ prior to, as well as during, the 2-d treatment with the inducers.

Immunofluorescence. The immunostaining procedures were carried out at $4^{\circ} \mathrm{C}$ using either $96-$ microwell plates or tissue culture chamber slides (Nunc, Inc., Naperville, $\mathbb{I}$ ). The cells were washed twice with PBSA (PBS containing $1 \% \mathrm{BSA}$ and $0.1 \% \mathrm{NaN}_{3}$ ) and were incubated for 45 
min with the appropriate primary MAb under saturating conditions. The cells were then washed again twice with PBSA and incubated for an additional $45 \mathrm{~min}$ with the secondary antibody $\mathrm{CY} 3^{\mathrm{TM}}$. After an additional wash with PBSA, the slides were mounted with phosphate-buffered Gelvatol $^{\mathrm{TM}}$ (Becton Dickinson, Sunnyvale, CA). Fluorescence was examined using a MAC Digital Confocal microscope.

RT-PCR Analysis. RNA was purified by centrifugation through a $\mathrm{CsCl}$ cushion as previously described (14). cDNA was synthesized from total cellular RNA using SuperScript ${ }^{\mathrm{TM}}$ II reverse transcriptase (GibcoBRL) and the conditions recommended by the supplier. The reverse transcription (RT) reaction used $2 \mu \mathrm{g}$ of total RNA and either $100 \mathrm{ng}$ of oligo(dT) primer or 2 pmol of a gene-specific primer. Polymerase chain reaction (PCR) amplification used the $T f l$ polymerase (Stratagene) and conditions recommended by the supplier. The FN template primers, F1F/F2R (nucleotides [nt] 3945-3966 and 4325-4346; 396-bp product) and F5F/F6R (nt 3981-4001; 746-bp product) were derived from the human sequence (Genbank accession number X02761). The combination of primer F1F and F6R resulted in a 782-bp PCR product. The template primers for human glyceraldehyde-3-phosphate dehydrogenase (GAPDH), G1F/G2R (nt 713-734; 715-bp product), were derived from the human sequence (Genbank accession number X01677). One set of cycle parameters were used for all primers (denaturation at $94^{\circ} \mathrm{C}, 50$ seconds; annealing at $63^{\circ} \mathrm{C}, 1 \mathrm{~min}$; extension at $73^{\circ} \mathrm{C}, 1 \mathrm{~min}$ ) with the total number of cycles $(25-40)$ tailored to the specific primer pair. For all reactions, various amounts of the reverse transcriptase reaction were used to insure correspondence between the amount of amplified product and the input cDNA. For the FN amplification reactions, at least three independent 
primers pairs were used for each set of reverse transcriptase products to validate the amplification pattern.

\section{RESULTS}

Manifestation of the $\beta_{1}$ integrin family and fibronectin during human macrophage differentiation. The $\beta_{1}$ integrin family (VLA) and FN are adhesion molecules implicated in the differentiation of a number of human cell types $(2,15)$. To determine whether they are also involved in human macrophage differentiation, we examined VLA and FN antigens on the surface of viable human HL-60 myeloid leukemia cells and on human monocytes during differentiation induced by either PMA or M-CSF. Untreated HL-60 cells, whether cultured for $4 \mathrm{~h}$ or $2 \mathrm{~d}$, exhibited some VLA immunostaining and little or no FN immunostaining. Treatment of these cells with $3 \mathrm{nM}$ PMA for $4 \mathrm{~h}$ caused the majority of the cells to display more intense immunostaining for both antigens. Prolonging this treatment to $2 \mathrm{~d}$, which causes the HL-60 cells to acquire a macrophage phenotype (11), resulted in a marked increase in VLA immunostaining and a lesser increase in FN immunostaining scattered throughout the surface of the cells (Fig. 1). In contrast, treatment of HL-60 cells for up to $2 \mathrm{~d}$ with $240 \mathrm{U} / \mathrm{ml} \mathrm{M}-\mathrm{CSF}$, which does not evoke a macrophage phenotype (16), failed to cause an increase in either VLA or FN immunostaining.

We also examined the immunostaining pattern of the $\alpha_{5}$ antigen, which associates with $\beta 1$ integrin and binds FN through its RGDS motif (2). The immunostaining pattern and intensity 
of $\alpha_{5}$ in untreated and PMA-treated HL-60 cells (not shown) corresponded to that of VLA shown in Fig. 1. These studies indicate macrophage differentiation is associated with increased levels of FN and the $\alpha_{5} \beta_{1}$ integrin.

Because integrins belonging to other families may also be involved in macrophage differentiation, we examined the immunostaining pattern of $\alpha_{v} \beta_{3}$ integrin, which also binds $F N$ through its $\operatorname{RGDS}$ motif $(2,17)$. For comparison, we included $M A b$ to the $\beta_{4}$ integrin which binds to laminin but not to FN (18). Untreated HL-60 cells exhibited little or no immunostaining with the $\alpha_{v} \beta_{3}$ MAb. After treatment for $2 \mathrm{~d}$ with PMA, $50 \%$ of the cells reacted with the MAb; however, the immunofluorescence was less intense than that observed in PMA-treated cells reacting with the VLA MAb. In contrast, untreated HL-60 cells showed reactivity with the $\beta_{4}$ MAb, but the reactivity decreased markedly after PMA treatment.

Freshly isolated peripheral blood monocytes exhibited weak immunostaining for VLA and FN. After two days in culture, the cells displayed some immunostaining for these antigens (Fig. 2). Treatment of the isolated monocytes with either $3 \mathrm{nM}$ PMA or $240 \mathrm{U} / \mathrm{ml}$ M-CSF for $2 \mathrm{~d}$ caused a marked increase in the intensity of the immunostaining, which was scattered throughout the surface of the cells. The treated cells also exhibited a typical macrophage cell spreading (Fig. 2).

A noteworthy observation was the abundance of speckled FN immunostaining in the intercellular spaces of the dishes containing activated monocytes or HL-60 macrophages, but not in those 
containing control cells (Figs. 1 and 2). Limited, scattered intercellular VLA immunostaining was also observed in the vicinity of the adherent macrophages (Figs. 1 and 2). Little or no immunostaining with the isotypic control antibodies was observed in untreated cells. Differentiated monocytes or HL-60 cells yielded weak immunostaining with these antibodies, which we regarded as background.

To provide evidence that protein kinase C (PKC) is not only involved in PMA- and M-CSFinduced macrophage differentiation $(11,19)$, but also in the VLA and FN immunostaining, we examined the effect of H-7, an inhibitor of PKA, PKC, and PKG, and HA-1004, an inhibitor of PKA and PKG but not PKC $(20,21)$. In treated monocytes and HL-60 cells, $20 \mu \mathrm{M} \mathrm{H}-7$ (but not $100 \mu \mathrm{M}$ HA-1004) decreased by about $70 \%$ the number of cells exhibiting macrophage markers, as well as the VLA and FN immunostaining. H-7 or HA-1004 failed to evoke such markers or to affect VLA and FN immunostaining in control HL-60 cells or monocytes.

Inhibition of PMA-induced macrophage differentiation in HL-60 cells. We tested the RGDS peptide and MAbs to FN and specific integrins for the ability to alter macrophage differentiation in HL-60 cells. Our results indicated that the anti-FN, anti-VLA and anti- $\alpha_{5}$ MAbs and the RGDS peptide attenuated the manifestation of PMA-evoked macrophage markers such as cell adherence and spreading, staining for non-specific esterase activity, and phagocytosis (Table 1). Moreover, the anti-FN, anti-VLA, and anti- $\alpha_{5}$ antibodies and the exogenous RGDS peptide inhibited the PMA-evoked reduction in the number of cells (Table 1), which to a large degree is due to apoptosis (22). We also tested the MAbs to the $\alpha_{v} \beta_{3}$ and $\beta_{4}$ integrins for their ability 
to inhibit cell adherence and spreading. The $\alpha_{v} \beta_{3}$ MAb caused a reduction of $25-30 \%$ in adherence and spreading and in phagocytosis. In contrast, the $\beta_{4} \mathrm{MAb}$ failed to affect these markers in the PMA-treated cells. Control antibodies and the control peptide GPRP had no effect on the expression of the PMA-induced markers or on the reduction in the number of cells (Table 1). The MAbs or the peptides also had little or no effect on the replication or expression of maturation markers in control HL-60 cells (Table 1).

Restoration of FN immunostaining in PMA-resistant cells. We studied cells from two HL-60 cell variants, HL-525 and HL-534 (9). Unlike the parental cells, these cells show diminished PKC $\beta$ gene expression and are resistant to PMA-induced macrophage differentiation $(9,10)$. Relative to the parental HL-60 cells, HL-525 cells had a strikingly higher intensity of $\beta_{1}$ and $\alpha_{5}$ immunofluorescence, and HL-534 cells had a much lower, barely visible, immunostaining for these antigens. In both variants, treatment with $30 \mathrm{nM}$ PMA for up to $2 \mathrm{~d}$ caused a limited increase in $\beta_{1}$ and $\alpha_{5}$ immunostaining. Untreated cells or cells treated with PMA failed to show FN immunostaining. Untreated and PMA-treated HL-525 cells also failed to exhibit reactivity with the anti- $\alpha_{\mathrm{v}} \beta_{3}$ and anti- $\beta_{4} \mathrm{MAb}$.

We have previously demonstrated that reestablishment of a functional PKC $\beta$ in HL-525 cells (via transfection with vectors containing PKC $\beta$ cDNA) restored their susceptibility to PMA-induced differentiation (11). The analysis of two PMA-treated transfectants revealed that the fraction of their cells that differentiated also regained FN immunostaining patterns and intensities like those of the corresponding PMA-treated HL-60 cells (Table 2). The tendency of these transfected cells 
to revert to the PMA-resistant phenotype (11) accounts for the fraction of the transfected HL-525 cells which were not susceptible to PMA-induced differentiation and FN immunostaining. No restoration of FN immunostaining was observed in HL-525 cells transfected with the control vector (Table 2). Another way to restore PKC $\beta$ gene expression and PMA susceptibility HL-525 cells is by preireatment with RA (23). Treatment with RA followed by PMA caused FN immunostaining patterns and intensities similar to those of PMA-treated HL-60 cells (Table 2). Treatment of HL-525 cells with either RA or PMA alone failed to induce FN immunostaining or macrophage differentiation (Table 2).

Restoration of susceptibility to macrophage differentiation in HL-525 cells by exogenous FN. We cultured HL-525 and HL-534 cells on dishes precoated with human FN, which resulted in a time-dependent increase in markers such as adherence and spreading, non-specific esterase activity, and phagocytosis in HL-525 cells, but not in HL-534 cells. After two days, more than $65 \%$ of the HL-525 cells had acquired a macrophage phenotype (Fig. 3, Table 3). PMA treatment of HL-525 cells cultured on FN-precoated dishes caused a further increase in this percentage, to about $85 \%$. No significant cell attachment and spreading was detected on dishes precoated with BSA, polylysine, or other ECM proteins such as laminin, type I collagen, or type IV collagen.

No significant cell adherence and spreading was observed on any of the precoated dishes when untreated HL-60 cells were used, which we attribute to a low level of inactive FN-binding integrins (24). To test for this possibility, we incubated HL-60 cells on FN-precoated dishes in 
the absence and presence of $\mathrm{MnCl}_{2}$, which can activate integrin binding to $\mathrm{FN}(25,26)$. For comparison we included HL-525 and HL-534 cells. After $1 \mathrm{~h}$ in the absence of $\mathrm{MnCl}_{2}$, the attachment of $\mathrm{HL}-60$ and HL-534 cells was $<1 \%$ and that of HL-525 cells $60 \%$. Incubation for $1 \mathrm{~h}$ with $1 \mathrm{mM} \mathrm{MnCl}{ }_{2}$ resulted in about $5 \%$ attachment of $\mathrm{HL}-534$ cells, which exhibit little or no $\beta_{1}$ and $\alpha_{5}$ antigens; $40 \%$ attachment of HL-60 cells, which exhibit some levels of these integrins; and $>90 \%$ attachment of HL-525 cells, which exhibit an abundance of FN-binding integrins. Thus, $\mathrm{MnCl}_{2}$-induced attachment to $\mathrm{FN}$ correlates to the level of $\mathrm{FN}$-binding integrins. Incubation of these cells for longer time periods of (up to $24 \mathrm{~h}$ ) in $\mathrm{MnCl}_{2}$ resulted in cytotoxicity.

Unlike PMA-induced differentiation in HL-60 cells, FN-induced macrophage differentiation of HL-525 cells was not affected by either the presence of $50 \mu \mathrm{M} \mathrm{H}-7$ or $200 \mu \mathrm{M} \mathrm{H}-1004$. H-7 and HA-1004 at higher doses evoked up to $30 \%$ cell death, as determined by trypan blue staining.

To substantiate the involvement of VLA and RGDS, we tested the effect of the anti-VLA MAb and exogenous RGDS on FN-induced macrophage differentiation of HL-525 cells. For comparison, we included the anti-FN MAb. HL-525 macrophage differentiation on human FNprecoated dishes was inhibited in the presence of anti-FN, anti-VLA MAb, and exogenous RGDS, but not in the presence of control reagents (Table 3).

Expression of the VLA and FN genes in HL-60 and HL-525 cells. We analyzed the steadystate levels of VLA and FN mRNA. The $\beta_{1}$-chain VLA mRNA level of HL-525 cells was higher than that of HL-60 cells. PMA treatment of HL-60 cells increased the mRNA level in a time- 
dependent manner, with the steady-state level of $\beta_{1}$-chain VLA mRNA already elevated about twofold at $4 \mathrm{~h}$. An attempt to assess FN mRNA by standard hybridization of an FN probe to total RNA or polyA-enriched RNA yielded inconsistent results. To circumvent this problem, we introduced semiquantitative RT-PCR analysis. Using this approach with three different sets of primers (including one that codes for RGDS), we observed.FN-specific amplification products in untreated HL-60 cells and elevated levels $4 \mathrm{~h}$ after PMA treatment (Fig. 4). These products were either absent or detected at low levels in untreated and PMA-treated HL-525 cells (Fig. 4). In contrast, PMA-induced FN-specific amplification products were detected in HL-525 cells transfected with PKC $\beta$ cDNA or pretreated with RA, but not in HL-525 cells transfected with the control vector or treated with RA alone (Fig. 4).

Inhibition of macrophage differentiation in monocytes by anti-VLA or anti-FN MAb. To assure that the involvement of an interaction between FN and VLA is not restricted to macrophage differentiation in the HL-60 cell system, we included peripheral blood monocytes in our studies. These cells, which are at a maturation stage close to macrophages, can acquire a macrophage phenotype after treatment with either PMA or M-CSF $(27,28)$. Our results indicated that after $2 \mathrm{~d}$ in culture, about $25 \%$ of the adherent monocytes (controls) exhibited the spreading typical of a macrophage. Two days of treatment of monocytes with either PMA or MCSF caused more than a twofold increase in the percentage of these macrophages. This treatment, however, failed to markedly alter the fraction of cells exhibiting phagocytosis (Table 4), because most macrophage markers also characterize monocytes. The anti-FN and anti-VLA MAbs were each able to reduce the fraction of spread cells in the PMA- and the M-CSF-treated 
monocytes; anti-FN MAb also reduced the fraction of spread cells in the control (Table 4). These two MAbs were each also able to reduce the fraction of cells exhibiting phagocytosis in both the untreated and the treated monocytes (Table 4).

\section{DISCUSSION}

We propose that induction and interaction of cellular receptors such as integrins with specific ECM proteins (which are secreted by the cells and deposited on foreign substrates) are steps in a process that brings about macrophage differentiation in appropriate progenitor cells. We focused our attention on the $\beta_{1}$ integrin family of receptors and fibronectin, because these adhesion proteins have been reported to be present in blood macrophages $(29,30)$. We used HL60 cells and peripheral blood monocytes for these studies because they can acquire a macrophage phenotype upon treatment with specific stimuli $(11,27,28,31)$.

In our initial experiments, we determined the cell surface level of VLA and FN antigens in HL60 cells and monocytes by immunostaining with specific MAbs. PMA treatment of HL-60 cells, and PMA or M-CSF treatment of monocytes, resulted in an increased level of these antigens in a time-dependent manner. Moreover, in HL-60 cells, the levels of FN and VLA antigens and the corresponding RNA transcripts were already increased at $4 \mathrm{~h}$ after treatment with the inducer, a time frame that precedes the acquisition of the mature phenotype $(27,32-36)$. In the case of FN, increased expression was associated with its secretion and deposition on the dishes. 
Additional support for an association between macrophage differentiation and FN came from our studies with HL-525 cells, which are deficient in protein kinase $C \beta$ and resistant to PMAinduced macrophage differentiation (10). These cells, whether treated with the macrophage inducer or not, failed to exhibit FN. Yet, FN immunostaining was found after restoration of PMA-induced macrophage differentiation by either transfection with PKC $\beta$ cDNA (11) or by pretreatment with all-trans-retinoic acid, which also elevates the expression of the PKC $\beta$ gene (23). Analysis of FN and VLA RNA steady-state levels by RT-PCR and Northern blotting, respectively, implicated gene expression as a major contributing factor in determining the level of these antigens in $\mathrm{HL}-60$ and $\mathrm{HL}-525$ cells. In this context, note that $\beta$ - or $\alpha$-chain VLA RNA transcripts were reported in M-CSF-treated human monocytes (35) and in a number of normal and leukemic human blood cells, including HL-60 cells (30).

Proof that increased levels of FN and VLA are intimately involved in the induction process itself came from our two experimental approaches. In one approach, we tested the ability of anti-VLA, anti-FN MAb, and the RGDS peptide to block macrophage differentiation in HL-60 cells and monocytes. We assumed that these molecules would prevent the interaction of VLA with the deposited FN, with its RGDS motif in particular. If this interaction is critical for macrophage differentiation, then the presence of either antibody or the peptide should inhibit such differentiation. Our studies indicate that indeed both the anti-VLA and anti-FN MAbs were able to attenuate macrophage differentiation in monocyte and HL-60 cells. Because other integrin families might also be involved in the interaction with FN (2), we included a MAb to $\alpha_{v} \beta_{3}$, an integrin that is present in cultured human macrophages (35) and that also binds FN through its 
RGDS motif (17). This antibody, which had limited reactivity with PMA-treated HL-60 cells, inhibited the expression of macrophage markers in these treated cells, but to a lesser degree than the anti-VLA MAb. These results indicate that induction of macrophage differentiation involves the production and interaction of VLA and related integrins with FN, which is produced, released, and deposited on suitable substrates, most likely with its RGDS motif.

In another type of experiment, we used HL-525 cells, which do not express the PKC $\beta$ and FN genes. We have shown that when these cells are either transfected with PKC $\beta$ cDNA (11) or pretreated with RA (23), they regain PKC $\beta$ expression and susceptibility to PMA-induced differentiation, as well as the expression of FN. Also, culturing HL-525 cells (which express a higher level of the VLA antigen than HL-60 cells) on FN-precoated dishes caused their differentiation to macrophages even in the absence of PMA. No such differentiation was observed with dishes precoated with other ECM proteins such as laminin or type I or type IV collagens. The FN-induced differentiation was also inhibited by the anti-FN and anti-VLA MAbs and by RGDS. These studies further implicate the involvement of FN and its interaction with suitable integrins for the attainment of a macrophage phenotype. Similar experiments (15) have shown that thymocyte differentiation also involves the presence and interaction of VLA with FN. In specific cases such as chimeric mice deficient in VLA (36), other integrins (as represented in our study by $\alpha_{v} \beta_{3}$ ) may become the critical factor.

Our results are also consistent with the involvement of PKC in the manifestation of FN, but not in the steps that follow the interaction of FN with such receptor molecules. This conclusion is 
based on the following: a) PMA, an activator of PKC, induced the expression of the VLA and FN genes in both the HL-60 cells and monocytes; b) transfection of the HL-525 cells with PKC $\beta$ cDNA or pretreatment with RA (an inducer of PKC $\beta$ ) restored the PMA-evoked manifestation of FN and macrophage differentiation; c) $\mathrm{H}-7$, but not $\mathrm{H}-1004$, prevented the appearance of VLA and FN and macrophage differentiation in HL-60 cells or monocytes; ana d) neither $\mathrm{H}-7$ nor $\mathrm{HA}-$ 1004 inhibited FN-induced macrophage differentiation in HL-525 cells.

We propose that macrophage differentiation in human progenitor cells induced by PMA or MCSF involves the activation of PKC, and phosphorylation of a variety of proteins, $(37,38)$, in turn leading to the expression of early response genes $(11,39)$. Products of these genes may then elicit the expression of other genes, such as those for integrins and ECM proteins, including FN, with the latter being produced, released, and deposited on foreign substrates. The stimulated cells, through their activated integrins, will attach and spread on these substrates by binding to the deposited FN and related ECM proteins. This attachment and spreading would then lead to the expression of the genes that characterize the macrophage phenotype. 
Table 1. Inhibition of PMA-induced macrophage differentiation in HL-60 cells by anti-FN, anti-VLA, or anti- $\alpha_{5}$ MAbs or by RGDS

\begin{tabular}{|c|c|c|c|c|c|c|c|c|}
\hline \multirow[b]{2}{*}{ Inhibitor } & \multicolumn{2}{|c|}{$\begin{array}{c}\text { Number of cells } \\
\left(10^{5} / \mathrm{ml}\right)\end{array}$} & \multicolumn{2}{|c|}{$\begin{array}{c}\text { Adherent and spread } \\
\text { cells }(\%)\end{array}$} & \multicolumn{2}{|c|}{$\begin{array}{c}\text { Cells showing } \\
\text { nonspecific esterase } \\
\text { activity }(\%)\end{array}$} & \multicolumn{2}{|c|}{$\begin{array}{c}\text { Phagocytizing cells } \\
(\%)\end{array}$} \\
\hline & - & $+\mathrm{PMA}$ & - & $+\mathrm{PMA}$ & - & +PMA & - & +PMA \\
\hline Control & $8.0 \pm 0.3$ & $2.6 \pm 0.3$ & $\leq 1$ & $91 \pm 7$ & $\$ 3$ & $68 \pm 5$ & $\$ 3$ & $83 \pm 9$ \\
\hline \multicolumn{9}{|l|}{ Antibodies } \\
\hline Anti-FN & $7.3 \pm 0.5$ & $4.4 \pm 0.3$ & $\leq 1$ & $17 \pm 7$ & $3 \pm 2$ & $18 \pm 2$ & $8 \pm 4$ & $27 \pm 11$ \\
\hline Anti-VLA & $7.6 \pm 0.1$ & $3.8 \pm 0.3$ & $\leq 1$ & $35 \pm 4$ & $\leq 3$ & $34 \pm 3$ & $5 \pm 1$ & $33 \pm 5$ \\
\hline Anti- $\alpha_{s}$ & $7.2 \pm 0.2$ & $4.1 \pm 0.3$ & $\leq 1$ & $32 \pm 7$ & $\mathrm{NT}$ & NT & $4 \pm 1$ & $38 \pm 6$ \\
\hline IgG & $7.5 \pm 0.4$ & $2.5 \pm 0.4$ & $\leq 1$ & $87 \pm 4$ & $\leq 3$ & $65 \pm 6$ & $3 \pm 1$ & $84 \pm 11$ \\
\hline Peptides & & & & & & $\cdot$ & & \\
\hline RGDS & $7.1 \pm 0.4$ & $3.5 \pm 0.1$ & $\leq 1$ & $45 \pm 10$ & $\leq 3$ & $40 \pm 5$ & $\leq 3$ & $42 \pm 5$ \\
\hline GPRP & $7.3 \pm 0.2$ & $2.9 \pm 0.2$ & $\leq 1$ & $88 \pm 8$ & $\leq 3$ & $76 \pm 1$ & $\leq 3$ & $73 \pm 8$ \\
\hline
\end{tabular}

The cells were incubated for $2 \mathrm{~d}$ with $3 \mathrm{nM}$ PMA in the presence or in the absence of the antibodies or peptides: $70 \mu \mathrm{g} / \mathrm{ml}$ anti-FN or anti-VLA MAb (or isotypic control MAb, IgG) or $700 \mu \mathrm{g} / \mathrm{ml}$ RGDS peptide (or control peptide, GPRP). The results represent the mean \pm SD of 3-8 independent experiments. NT, not tested. 
Table 2. Association between acquisition of a PMA-induced macrophage phenotype and induction of FN immunostaining in HL-60 and HL-525 cells.

\begin{tabular}{|c|c|c|c|c|}
\hline \multicolumn{2}{|c|}{ Treatment } & $\begin{array}{l}\text { Adherent and spread } \\
\text { cells (\%) }\end{array}$ & $\begin{array}{l}\text { Cells reactive with } \\
\text { anti-FN MAb }\end{array}$ & $\mathrm{IgG}^{*}$ \\
\hline \multicolumn{5}{|l|}{ HL-60 } \\
\hline $2 \mathrm{~d}$ control & & $<1$ & $<1$ & $<1$ \\
\hline $2 d \mathrm{PMA}$ & & $87 \pm 5$ & $77 \pm 4$ & $7 \pm 4$ \\
\hline \multicolumn{5}{|l|}{ HL-525 } \\
\hline $2 \mathrm{~d}$ control & & $<1$ & $<1$ & $3 \pm 1$ \\
\hline 2 d PMA & & $<1$ & $<1$ & $4 \pm 2$ \\
\hline \multicolumn{5}{|l|}{$\mathrm{HL}-525{ }^{\mathrm{NEO}}$} \\
\hline $2 \mathrm{~d}$ control & & $<1$ & $<1$ & $5 \pm 3$ \\
\hline 2 d PMA & & $<1$ & $<1$ & $3 \pm 1$ \\
\hline \multicolumn{5}{|l|}{$\mathrm{HL}-525 / \beta_{1}-\mathrm{C}$} \\
\hline $2 \mathrm{~d}$ control & & $<1$ & $<1$ & $<1$ \\
\hline 2 d PMA & & $32 \pm 7$ & $28 \pm 9$ & $7 \pm 5$ \\
\hline \multicolumn{5}{|l|}{$\mathrm{HL}-525 / \beta_{1}-\mathrm{F}$} \\
\hline $2 \mathrm{~d}$ control & & $<1$ & $<1$ & $8 \pm 3$ \\
\hline $2 d \mathrm{PMA}$ & & $45 \pm 7$ & $40 \pm 9$ & $5 \pm 2$ \\
\hline \multicolumn{5}{|l|}{ HL-525 } \\
\hline$\underline{3 d}$ & $\underline{2 d}$ & & . & \\
\hline control & control & $<1$ & $<1$ & $2 \pm 1$ \\
\hline ATRA & control & $<1$ & $<1$ & $4 \pm 3$ \\
\hline control & PMA & $<1$ & $4 \pm 2$ & $9 \pm 5$ \\
\hline ATRA & PMA & $62 \pm 10$ & $57 \pm 3$ & $11 \pm 2$ \\
\hline
\end{tabular}

HL- 60 cells were treated with 3 nM PMA while HL-525 cells and the transfectant with $30 \mathrm{nM}$ PMA. The concentration of RA was $1 \mu \mathrm{M}$. The results represent the means \pm SD of 2-6 independent experiments.

${ }^{*} \operatorname{IgG}$ column represents results obtained with mouse $\operatorname{IgG}_{2} \beta$ antibody, which was used as a control for the anti-FN MAb. 
Table 3. Inhibition of human FN-induced macrophage differentiation in HL-525 cells by anti-FN or anti-VLA MAb or by RGDS.

\begin{tabular}{|c|c|c|c|c|c|c|c|c|}
\hline \multirow[b]{2}{*}{ Inhibitor } & \multicolumn{2}{|c|}{$\begin{array}{c}\text { Number of cells } \\
\left(10^{5} / \mathrm{ml}\right)\end{array}$} & \multicolumn{2}{|c|}{$\begin{array}{l}\text { Adherent and spread cells } \\
(\%)\end{array}$} & \multicolumn{2}{|c|}{$\begin{array}{c}\text { Cells showing nonspecific } \\
\text { esterase activity }\left(\varphi_{0}\right)\end{array}$} & \multicolumn{2}{|c|}{$\begin{array}{l}\text { Phugacytizing cells } \\
\qquad(\%)\end{array}$} \\
\hline & BSA & FN & BSA & FN & BSA & $\mathrm{FN}$ & BSA & FN \\
\hline Control & $8.2 \pm 0.5$ & $3.3 \pm 0.6$ & $\leq 1$ & $70 \pm 10$ & $2 \pm 1$ & $65 \pm 1$ & $2 \pm 1$ & $76 \pm 4$ \\
\hline \multicolumn{9}{|l|}{ Antibodies } \\
\hline Anti-VLA & $7.5 \pm 0.9$ & $3.9 \pm 0.2$ & $3 \pm 2$ & $34 \pm 2$ & $4 \pm 1$ & $35 \pm 13$ & $5 \pm 3$ & $26 \pm 12$ \\
\hline $\mathrm{IgG}$ & $7.8 \pm 0.4$ & $3.4 \pm 0.3$ & $3 \pm 1$ & $73 \pm 9$ & $2 \pm 1$ & $62 \pm 7$ & $3 \pm 2$ & $84 \pm 7$ \\
\hline \multicolumn{9}{|l|}{ Peptides } \\
\hline RGDS & $7.8 \pm 0.3$ & $4.3 \pm 0.5$ & $2 \pm 1$ & $23 \pm 12$ & $3 \pm 1$ & $15 \pm 10$ & $3 \pm 2$ & $30 \pm 15$ \\
\hline
\end{tabular}

Cells were incubated for $2 \mathrm{~d}$ on the BSA- or FN-coated wells in the presence or in the absence of the antibodies or peptides: $70 \mathrm{pg} / \mathrm{ml}$ anti-FN or anti-VLA MAb (or isotypic control, $\mathrm{IgG}$ ) or $700 \mu \mathrm{g} / \mathrm{ml}$ RGDS peptide (or control peptide, GPRP). The results are the mean \pm SD of 3-5 independent experiments. 
Table 4. Inhibition of PMA- or M-CSF-induced macrophage differentiation in peripheral blood monocytes by either anti-FN or anti-VLA MAb.

\begin{tabular}{lccccccc}
\hline & \multicolumn{2}{c}{ Adherent and spread cells (\%) } & & \multicolumn{3}{c}{ Phagocytizing cells (\%) } \\
\cline { 2 - 4 } \cline { 6 - 8 } & - & PMA & M-CSF & & - & PMA & M-CSF \\
\hline Control & $25 \pm 10$ & $70 \pm 14$ & $53 \pm 6$ & & $60 \pm 5$ & $75 \pm 5$ & $64 \pm 3$ \\
Antibodies & & & & & & & \\
$\quad$ Anti-FN & $8 \pm 2$ & $15 \pm 7$ & $26 \pm 3$ & & $41 \pm 5$ & $39 \pm 4$ & $33 \pm 2$ \\
Anti-VLA & $15 \pm 7$ & $30 \pm 12$ & $19 \pm 3$ & & $43 \pm 7$ & $35 \pm 2$ & $46 \pm 5$ \\
IgG & $25 \pm 12$ & $66 \pm 14$ & $56 \pm 4$ & & $63 \pm 9$ & $73 \pm 3$ & $60 \pm 8$ \\
\hline
\end{tabular}

The monocytes obtained from throe individuals were either treated or untreated for $2 \mathrm{~d}$ with $3 \mathrm{nM}$ PMA or $240 \mathrm{U} / \mathrm{ml}$ M-CSF in the presence or in the absence of antibodies or peptides: $70 \mu \mathrm{g} / \mathrm{ml}$ anti-FN or anti-VLA MAb (or isotypic control, $\mathrm{IgG}$ ). The results are the mean \pm SD 3-5 independent experiments. 


\section{Figure Captions}

Fig. 1 Manifestation of the VLA and FN antigens on the surface of untreated and PMA-treated HL-60 cells. Cells were either incubated in the absence or the presence of 3 nM PMA and were then reacted with the anti-VLA or anti-FN MAbs.

Fig. 2 Manifestation of the VLA and FN antigens on the surface of untreated or either PMA or MCSF-treated monocytes. Cells were either incubated for $48 \mathrm{~h}$ in the absence or the presence of $3 \mathrm{nM}$ PMA or $240 \mathrm{U} / \mathrm{ml}$ M-CSF.

Fig. 3 Attachment and spreading of HL-525 cells incubated in tissue culture dishes precoated for $48 \mathrm{~h}$ with either BSA (A) or FN (B). The pattern of FN (C) on the precoated dishes in the absence of cells was visualized after immunostaining with anti-FN MAb.

Fig. 4 RT-PCR analysis of FN mRNA levels in PMA-treated HL-60 cells (A), RA/PMA-treated HL525 cells (B), or PKC $\beta$-transfected HL-525 cells (C). HL-60 cells were treated with $3 \mathrm{nM}$ PMA; HL-525 cells with $30 \mathrm{nM}$ PMA* and/or $1 \mu \mathrm{M} \mathrm{RA;} \mathrm{and} \mathrm{PKC} \beta$-transfected HL-525 cells were treated with $30 \mathrm{nM}$ PMA. 


\section{REFERENCES}

1. Mosher, D. F., Sottile, J., Wu, C. \& McDonald, J. A. (1992) Current Opinion in Cell Biol. 4, 810-818.

2. Hynes, R. O. (1992) Cell 69, 11-25.

3. Lobb, R. R. \& Hemler, M. E. (1994) J. Clin. Invest. 94, 1722-1728.

4. Chen, Q., Kinch, M. S., Lin, T. H., Burridge, K. \& Juliano, R. L. (1994). J. Biol. Chem. 269, $26602-26605$.

5. Hershkoviz, R., Alon, R., Gilat, D. \& Lider, O. (1992) Cellular Immunology 141, $352-361$.

6. Kaplan, G. \& Gaudernack, G. (1982) J. Exp. Med. 156, 1101-1114.

7. Bohnsack, J. F., Kleinman, H. K., Takahashi, T., O’Shea, J. J. \& Brown, E. J. (1985) J. Exp. Med. 161, 912-923.

8. Gudewicz, P. W., Frewin, M. B., Heinel, L. A. \& Minnear, F. L. (1994) J. Leuk. Biol. 55.

9. Homma, Y., Henning-Chubb, C. B. \& Huberman, E. (1986) Proc. Natl. Acad. Sci. USA 83, $7316-7319$.

10. Tonetti, D. A., Horio, M., Collart, F. R. \& Huberman, E. (1992) Cell Growth Differen. 3, $739-745$.

11. Tonetti, D. A., Henning-Chubb, C., Yamanishi, D. T. \& Huberman, E. (1994) J. Biol. Chem. $269,23230-23235$.

12. Laouar, A., Wietzerbin, J. \& Bauvois, B. (1993) Int. Immunol. 5, 965-973.

13. Bauvois, B., Rouillard, D., Sanceau, J. \& Wietzerbin, J. (1992) J. Immunol. 148, 3912-3919.

14. Chirgwin, J. M., Przybyla, A. E., MacDonald, A. E. \& Rutter, W. J. (1979) Biochemistry 18, 5294-5299.

15. Utsumi, K., Sawada, M., Narumiya, S., Nagamine, J. Nagamine, Sakata, T., Iwagami, S., Kita, Y., Teráoka, H., Hirano, H., Ogata, M., Hamaoka, T. \& Fujiwara, H. (1991) Proc. Natl. 
Acad. Sci. USA 88, 5685-5689.

16. Vassiliadis, S. \& Guilbert, L. J. (1991) Exp. Hematol. 19, 250-256.

17. Yamada, K. M. (1989) Current Opinion in Cell Biol. 1, 956-963.

18. Mainiero, F., Pepe, A., Wary, K. K., Spinardi, L., Mohammadi, M., Schlessinger, J. \& Giancotti, F. G. (1995) EMBO J. 14, 4470-4481.

19. Imamura, K., Dianoux, A., Nakamura, T. \& Kufe, D. (1990) EMBO e. 9, 2423-2429.

20. Hidaka, H., Inagaki, M., Kawamoto, S. \& Sasaki, Y. (1984) Biochemistry 23, 5036-5041.

21. Asano, T. \& Hidaka, H. (1986) J. Pharmacol. Exp. Ther. 231, 141-145.

22. Ohta, H., Sweeney, E. A., Masamune, A., Yatomi, Y., Hakomori, S. \& Igarashi, Y. (1995) Cancer Res. 55, 691-697.

23. Yang, K. D., Mizobuchi, T., Kharbanda, S. M., Datta, R., Huberman, E., Kufe, D. W., \& Stone, R. M. (1994) Blood 83, 490-496.

24. Van De Water, L., Aronson, D. \& Braman, V. (1988) Cancer Res. 48, 5730-5737.

25. Bohnsack, J. F. \& Chang, J. (1994) Blood 83, 543-552.

26. Sigurdson, S. L: \& Lwebuga-Mukasa, J. S., (1994) Exper. Cell Res. 213, 71-79.

27. Becker, S., Warren, M. K. \& Haskill, S. (1987) J. Immunol. 139, 3703-3709.

28. Meenakshi, T. Ross, F. P., Martin, J. \& Teitelbaum, S. L. (1993) J. Cell Biochem. 53, $145-155$.

29. Alitalo, K., Hovi, T. \& Vaheri, A. (1980) J. Exp. Med. 151, 602-613.

30. Janiak, M., Sawicki, G. \& Janowska-Wieczorek. A. (1994) Leukemia 8, 1544-1550.

31. Murao, S., Gemmell, M. A., Callahan, M. F., Anderson, N. L. \& Huberman, E. (1983) Cancer Res. 43, 4989-4996.

32. Huberman, E., Weeks, C., Herrmann, A., Callahan, M. \& Slaga, T. (1981) Proc. Natl. Acad. Sci. USA 78, 1062-1066.

33. Hirata, T., Bitterman, P. B., Mornex, J.-F., \& Crystal, R. G. (1986) J. Immunol. 136, 1339- 
1345.

34. Jungi, T. W. \& Hafner, S. (1986) Immunology 58, 131-137.

35. De Nichilo, M. O. \& Burns, G. F. (1993) Proc. Natl. Acad. Sci. USA 90, 2517-2521.

36. Hirsh, E., Iglesias, A., Potocnik, A. J., Hartmanṇ, U. \& Fässler, R. (1996) Nature 380, $171-$ 175.

37. Seger, R. \& Krebs, E. G. (1995) FASEB J. 9, 726-735.

38. Posada, J. \& Cooper, J. A. (1992) Science 255, 212-215.

39. Chen, R.-H., Abate, C. \& Blenis, J. (1993) Proc. Natl. Acad. Sci. USA 90, 10952-10956. 


$$
\begin{gathered}
40 \quad 0 \quad 9 \\
0 \quad 0
\end{gathered}
$$
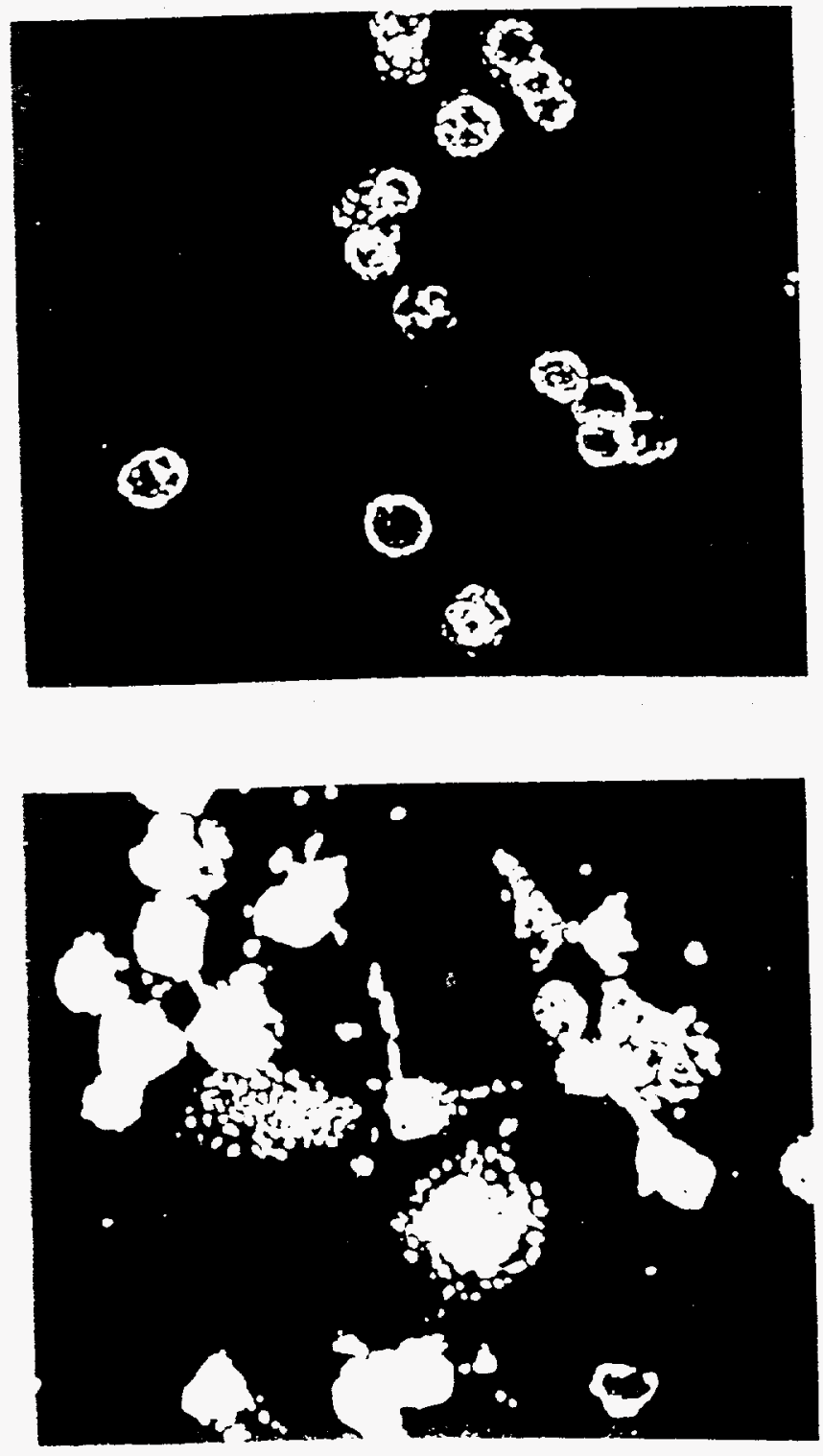

.10

)

Control $48 \mathrm{~h}$

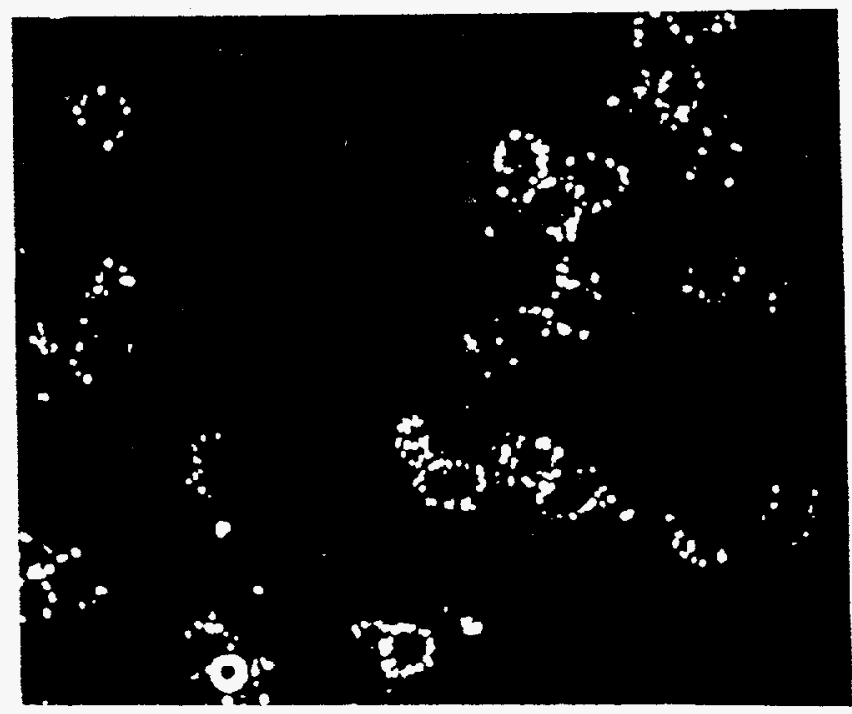

PMA $4 h$

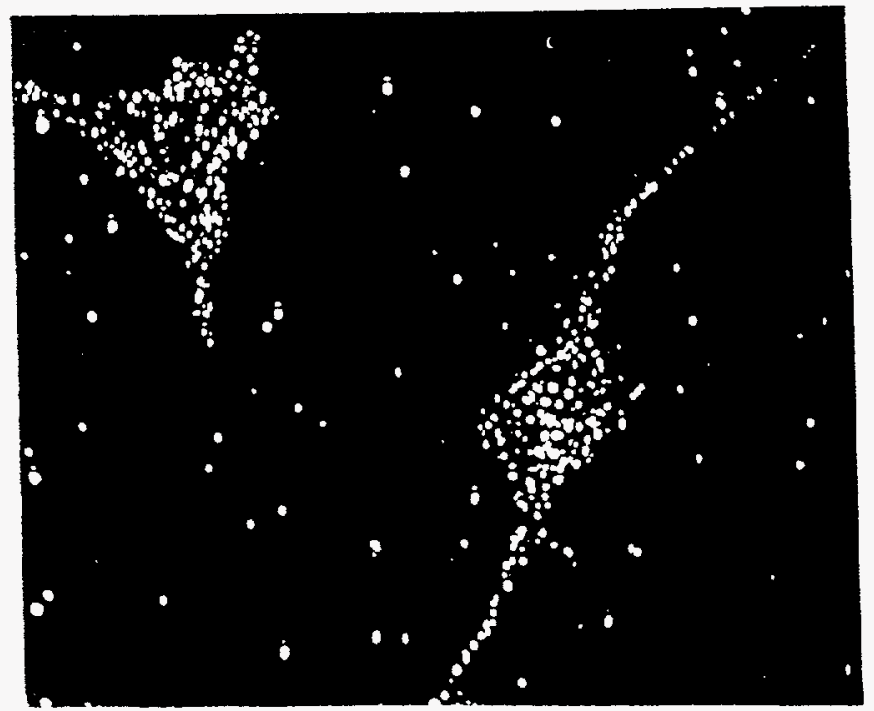

PMA 48h 

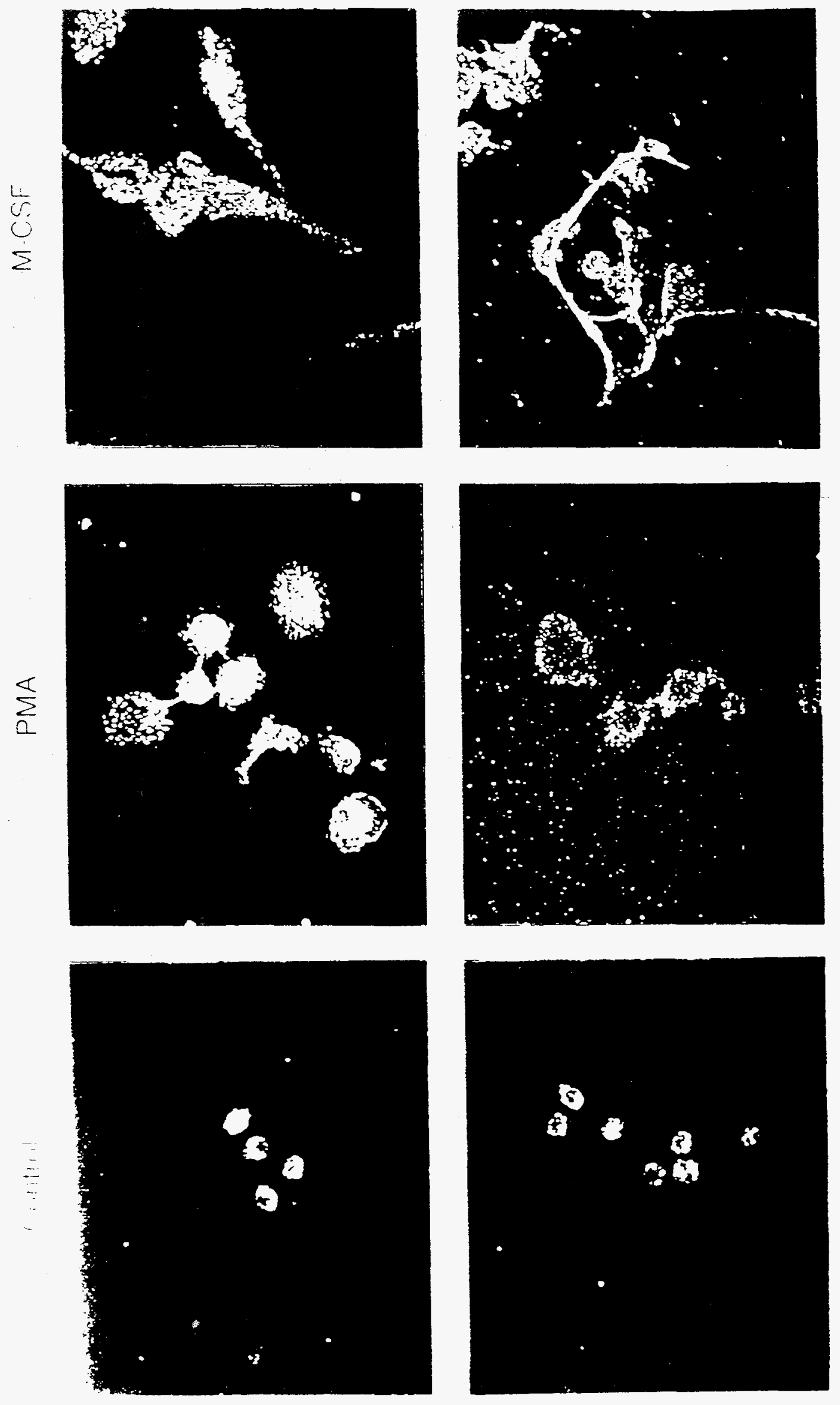


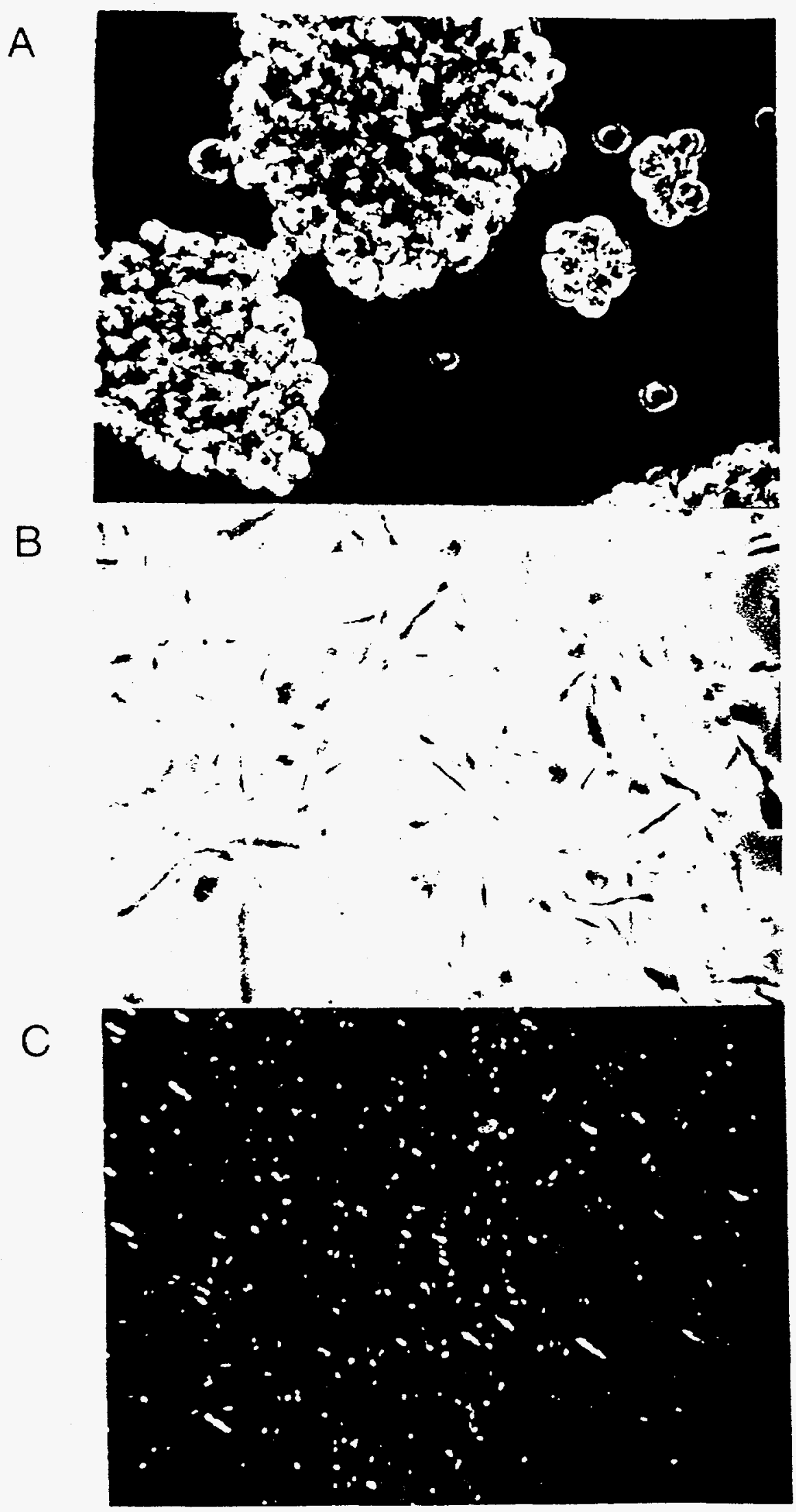




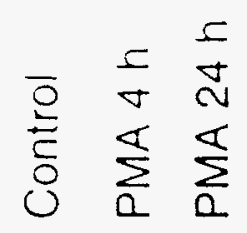

A

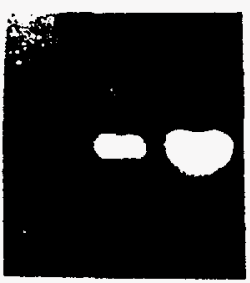

FN

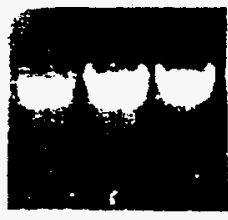

GAPDH

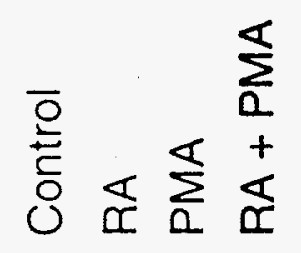

B

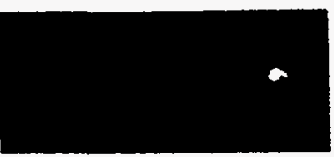

FN

$\bullet$

GAPDH

HL-525 HL-525/B $1-C$

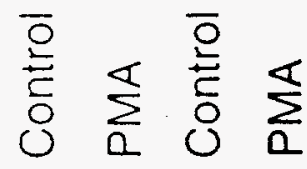

C

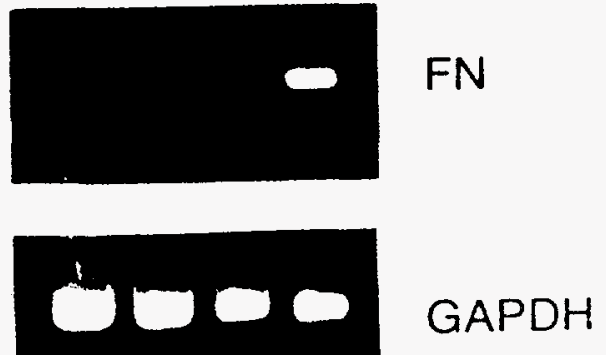

